\title{
THE RÔLE OF FSH AND LH IN THE INITIATION OF OVULATION IN RATS AND HAMSTERS: A STUDY USING RABBIT ANTISERA TO OVINE FSH AND LH
}

\author{
A. JAGANNADHA RAO,* N. R. MOUDGAL, \\ H. G. MADHWA RAJ, ${ }^{* *}$ H. LIPNER, $\dagger \ddagger$ AND R. O. GREEP $\dagger$ \\ Endocrinology Laboratory, Department of Biochemistry, Indian Institute of Science, \\ Bangalore 560012, India, \\ and $\uparrow$ Laboratory of Human Reproduction and Reproductive Biology, \\ Harvard Medical School, Boston, Massachusetts 02115, U.S.A.
}

(Received 24th April 1973)

Summary. The relative rôles of FSH and LH in ovulation induction in immature and adult cycling rats and hamsters have been evaluated. Both heterologous purified pituitary hormones and homologous crude pituitary extracts have been used as ovulatory stimuli in immature animals primed with PMSG. Well-characterized FSH and LH antisera have been used in the above model systems to achieve specific neutralization of FSH and LH. The present study revealed that $\mathrm{LH}$ is the physiological trigger needed for induction of ovulation in both rats and hamsters and FSH cannot, by itself, induce ovulation in the total absence of LH.

\section{INTRODUCTION}

Although several investigations in the past have shown the ability of $\mathrm{LH}$ to induce ovulation, the term 'ovulation inducing hormone(s)' continue to be used suggesting that ovulation-induction could be due to more than one hormonal stimulus. The reason for this thinking is the recent evidence which has accumulated in favour of FSH also being an ovulation inducer. This includes (a) the appearance of a concomitant FSH and LH release just before ovulation (McClintock \& Schwartz, 1968; Midgley \& Jaffe, 1968; Daane \& Parlow, 1971), (b) the ability of highly purified FSH (not more than $1 \% \mathrm{LH}$ contamination) to induce ovulation in hypophysectomized rats primed with PMSG (Lostroh \& Johnson, 1966), (c) the ability of exogenous 'cleansed' FSH (treated with chymotrypsin or urea-Harrington, Bex, Elton \& Roach (1970), or with LH antiserum-H. Lipner, N. R. Moudgal, G. J. Macdonald, S. Y. Ying \& R. O. Greep, unpublished results) to induce ovulation either in intact rats treated with chlorpromazine or in hypophysectomized rats, and

\footnotetext{
* Present address: Hormone Research Laboratory, University of Galifornia Medical Genter, San Francisco, Galifornia 94143, U.S.A.

* Present address: Laboratory of Human Reproduction and Reproductive Biology, 45 Shattuck Street, Boston, Massachusetts 02115, U.S.A. U.S.A.

Present address: Department of Biological Science, Florida State University, Tallahassee 32306,
} 
(d) the ability of general purpose gonadotrophin antiserum, reduced after absorption with NIH ovine FSH (Goldman \& Mahesh, 1969), to block ovulation in hamsters.

Since some of the conclusions from the above studies were questionable (e.g. (a) absorption of FSH antibodies, from an antiserum containing antibodies to both FSH and $\mathrm{LH}$, by $\mathrm{LH}$, and (b) making the tacit assumption that, in intact animals treated with chlorpromazine, there is a complete shut-off of both tonic and surge LH release), it was considered essential to reinvestigate the rôle of FSH per se in the ovulation process. In the present study, the ovulationinducing ability of FSH in the absence of LH and vice versa has been tested. A preliminary account, using rats (Moudgal, Jagannadha Rao, Madhwa Raj \& Maneckjee, 1970) and hamsters (Jagannadha Rao, Madhwa Raj \& Moudgal, 1971), has been reported earlier.

\section{Animals}

\section{MATERIALS AND METHODS}

The animals used were derived from the Indian Institute of Science colony. Immature albino rats on the 22nd day of age and golden hamsters on the 28th day of age received 20 i.u. PMSG (Ayerst) at 10.00 hours and $56 \mathrm{hr}$ later a dose of ovulating hormone, either in the form of purified ovine FSH or LH or as rat or hamster pituitary extract, was injected. Adult rats and hamsters which exhibited a minimum of three regular cycles were also used in these experiments. They received the appropriate antiserum injection at 10.00 hours on the day of pro-oestrus. Autopsies were performed 18 to $24 \mathrm{hr}$ after the administration of ovulatory hormone or antiserum. At autopsy, oviducts were dissected out, gently compressed between two glass slides and examined for ova under a microscope $(\times 40)$. Relevant groups were subjected to statistical analysis and probability was calculated by Student's $t$ test.

\section{Hormones}

The hormone preparations, NIH-FSH-S7 and S8, NIH-LH-S14, and PMSG were used. Highly purified preparations of ovine LH $(1 \times 2.5 \mathrm{NIH}-\mathrm{LH}-\mathrm{S} 1)$ and ovine FSH ( $1 \times 45$ NIH-FSH-S1) were used in the iodination and radiolabelled hormone-binding studies. The purified LH preparation was also used as an ovulation inducer.

\section{Antisera}

Potent antisera to NIH ovine FSH and ovine LH (Hormone Research Laboratory preparations) were raised in rabbits and characterized according to the methods described earlier (Moudgal \& Li, 1961; Jagannadha Rao \& Moudgal, 1970; Madhwa Raj \& Moudgal, 1970). The method of characterization of FSH antiserum was further refined and the details are given below.

Antiserum raised against NIH ovine FSH preparations was characterized by initial absorption with normal sheep serum and placental extract (see Jagannadha Rao \& Moudgal, 1970, for details). Antibodies to LH were specifically removed by a new method standardized in our laboratory. This involves incubating FSH antiserum $(1 \mathrm{ml})$ with $\mathrm{LH}$-coated tanned formalized red blood 
cells $(0.5 \mathrm{ml} 1 \%$ red blood cells coated with $0.165 \% \mathrm{NIH}$ ovine $\mathrm{LH})$ as a solid immunosorbent. After incubation (accompanied by mild stirring using a magnetic stirrer) at room temperature for $1 \mathrm{hr}$, the immunosorbent was removed by centrifugation and the supernatant antiserum was checked for the presence of LH antibody. The treatment with the immunosorbent was repeated if the absorption was found to be incomplete.

The ability of the antiserum to bind and neutralize $\mathrm{LH}$ was tested by using ${ }^{125}$ I-labelled LH in binding studies (Madhwa Raj \& Moudgal, 1970) and in the OAAD test of Parlow (1961) as modified by Sakiz \& Guillemin (1963). The binding study involved the incubation of $10 \mu$ l undiluted antiserum with ${ }^{125} \mathrm{I}$-labelled hormones for $24 \mathrm{hr}$ at $37^{\circ} \mathrm{C}$. The antigen-antibody complex was then precipitated by adding goat antibody to rabbit $\gamma$-globulin. The incubation was continued for a further $12 \mathrm{hr}$, the precipitated antigen-antibody complex was centrifuged and the radioactivity in the precipitate and supernatant was counted using a Packard $\gamma$-spectrometer. The binding experiment results presented are averages of three separate determinations.

\section{Bioassay}

The ability of FSH antiserum to achieve specific neutralization of the FSH activity of rat and hamster pituitary was checked in a total gonadotrophin assay. The validity of this assay to ascertain the efficacy of gonadotrophin antiserum to neutralize a gonadotrophin specifically has been described in an earlier communication (Jagannadha Rao \& Moudgal, 1970).

\section{RESULTS}

Detection of $L H$ antibodies in FSH antiserum by the OAAD test

The results presented in Table 1 show that FSH antiserum freed of antibodies to serum and tissue proteins (as ascertained by the Ouchterlony test) had sufficient antibodies to LH to be able to neutralize LH activity in the

Table 1. Ability of unabsorbed FSH antiserum to neutralize $\mathrm{LH}$ activity as tested in the OAAD assay

\begin{tabular}{|c|c|c|c|c|c|}
\hline Group* & $\begin{array}{l}\text { Treatment } \\
L H(\mu g)\end{array}$ & Antiserum & $\underset{\text { ovary }}{O A A / 100 \mathrm{mg}}$ & $\%$ depletion & $\stackrel{\mathrm{P}}{O A A}$ \\
\hline $\begin{array}{l}\text { I } \\
\text { II } \\
\text { III } \\
\text { IV }\end{array}$ & $\begin{array}{l}-1 \\
4 \\
4\end{array}$ & $\underset{\substack{\text { Nntiserum } \\
\text { (UA) }}}{-}$ & $\begin{array}{l}86 \cdot 7 \pm 3 \cdot 0 \\
42 \cdot 6 \pm 1 \cdot 6 \\
20 \cdot 2 \pm 1 \cdot 5 \\
66 \cdot 7 \pm 3.5\end{array}$ & $\begin{array}{l}-\overline{50 \cdot 7} \\
76 \cdot 6 \\
22 \cdot 8\end{array}$ & $\begin{array}{r}<0.0 \overline{1} \text { (I:II) } \\
<0.001 \text { (I :III) } \\
<0.001 \text { (III:IV) }\end{array}$ \\
\hline V & 4 & Antiserum (A) & $22 \cdot 1 \pm 1 \cdot 3$ & $74 \cdot 42$ & $<0.05($ III:V) \\
\hline
\end{tabular}

Female rats (25 days old) were primed with 100 i.u. PMSG and 40 i.u. HGG. The hormone and antiserum were given separately by the intraperitoneal route. The antiserum $(0.5 \mathrm{ml})$ was given immediately after the hormone injection. Autopsy was performed $4 \mathrm{hr}$ after the hormone injection, and the ovaries were processed for ascorbic acid.

$\mathrm{NRS}=$ normal rabbit serum (controls); $\mathrm{A}=$ absorbed antiserum; $\mathrm{UA}=$ unabsorbed antiserum.

* Five animals/group.

$$
\% \text { depletion of } \mathrm{OAA}=100-\frac{\mu \mathrm{g} \mathrm{OAA} / 100 \mathrm{mg} \text { of treated group } \times 100}{\mu \mathrm{g} \text { of } \mathrm{OAA} / 100 \mathrm{mg} \text { of ovary of saline control }}
$$


OAAD test (Table I, Groups III and IV). Absorption of LH antibodies by the method described (see 'Materials and Methods'), however, removed the contaminating antibodies completely (Table 1, Groups III and V).

\section{Binding studies with ${ }^{125}$ I-labelled hormones}

The ${ }^{125}$ I-labelled hormone-binding studies, the results of which are shown in Table 2, give a much clearer picture of the efficacy of the absorption procedure used here. Thus, while the FSH antiserum absorbed free of serum

Table 2. Characterization of antisera-labelled hormone binding studies

\begin{tabular}{l|l|c|c}
\hline \multirow{2}{*}{ Group } & \multicolumn{1}{|c|}{ Antiserum $(a / s)^{*}$} & ${ }^{125}$ I-labelled hormone & $\%$ specific binding \\
\hline II & FSH a/s unabsorbed & FSH & $58 \cdot 2$ \\
II & FSH a/s unabsorbed & LH & $39 \cdot 4$ \\
III & FSH a/s absorbed & FSH & $54 \cdot 7$ \\
IV & FSH a/s absorbed & LH & $1 \cdot 4$ \\
V & FSH a/s & FSH & $29 \cdot 0$ \\
VI & FSH a/s+50 ng LH & FSH & $28 \cdot 0$ \\
VII & FSH a/s+1 ng FSH & FSH & $11 \cdot 0$ \\
VIII & LH a/s & LH & $43 \cdot 0$ \\
IX & LH a/s +absorbed FSH a/s $(10 \mu \mathrm{l})$ & LH & $42 \cdot 0$ \\
X & LH a/s & FSH & $89 \cdot 0$ \\
XI & LH a/s & FSH & $1 \cdot 8$ \\
\hline
\end{tabular}

See text for details of incubation.

* In Groups I, II, III, IV, X, XI, $10 \mu$ undiluted antiserum was used. Other groups were given $100 \mu$ of $1: 1000$ diluted antiserum (absorbed).

and tissue proteins is able to bind both $\left[{ }^{125} \mathrm{I}\right] \mathrm{LH}$ and $\left[{ }^{125} \mathrm{I}\right] \mathrm{FSH}$ to a significant extent (Table 2, Groups I and II) following treatment with LH immunosorbent, the binding to LH is reduced almost to zero (Table 2, Group IV). The binding capacity of the antiserum to $\left[{ }^{125} \mathrm{I}\right] \mathrm{FSH}$, however, remains unchanged (Table 2, Group III). The specificity of the antiserum to bind $\left[{ }^{125} \mathrm{I}\right] \mathrm{FSH}$ was demonstrated by determining the extent of binding in the presence of cold FSH and LH, the latter being present in large excess (Table 2, compare Groups VI and VII with Group V).

The possibility that the use of $\mathrm{LH}$ immunosorbent might have resulted in leaching of $\mathrm{LH}$ from immunosorbent into the FSH antiserum had also to be checked since it was intended that this antiserum should be used specifically to block FSH without in any way contributing to the LH pool. This was done by determining the binding ability of $\left[{ }^{125} \mathrm{I}\right] \mathrm{LH}$ to $\mathrm{LH}$ antiserum in the presence and absence of immunosorbent-treated FSH antiserum. The presence of leached LH in FSH antiserum would have reduced the binding of LH antiserum (Table 2, compare Group VIII with Group IX) to LH.

The specificity of the LH antiserum to bind only LH was also checked using a similar system and the results show clearly the absence of FSH antibodies (Table 2, Groups X and XI).

\section{Ability of FSH antiserum to neutralize rat and hamster FSH}

Making use of the fact that total gonadotrophin assay is dependent upon the combined activity of FSH and LH, the ability of FSH antiserum freed of 
Table 3. The ability of absorbed FSH antiserum to neutralize the FSH activity of rat and hamster pituitary extract as checked in the total gonadotrophin assay using 21-day-old female mice

\begin{tabular}{|c|c|c|c|}
\hline Group & $\begin{array}{l}\text { No. of } \\
\text { animals }\end{array}$ & Treatment & $\begin{array}{l}\text { Uterine weight } \\
(m g \pm S . D .)\end{array}$ \\
\hline I & 5 & NRS* $0.5 \mathrm{ml}$ & $14 \cdot 0 \pm 1 \cdot 9$ \\
\hline II & 5 & $\begin{array}{l}\text { One adult rat pituitary extract } \\
+\mathrm{NRS} 0.5 \mathrm{ml}\end{array}$ & $59 \cdot 0 \pm 8 \cdot 4$ \\
\hline III & 5 & $\begin{array}{l}\text { One adult rat pituitary extract } \\
+0.5 \mathrm{ml} \text { absorbed } \mathrm{FSH} \mathrm{a} / \mathrm{s}\end{array}$ & $14 \cdot 3 \pm 4 \cdot 4$ \\
\hline IV & 3 & NRS* $0.5 \mathrm{ml}$ & $6 \cdot 5 \pm 1 \cdot 0$ \\
\hline V & 3 & $\begin{array}{l}\text { One adult male hamster pituitary } \\
\text { extract }+0.5 \mathrm{ml} \text { NRS }\end{array}$ & $49 \cdot 1 \pm 2 \cdot 8$ \\
\hline VI & 3 & $\begin{array}{l}\text { One adult male hamster pituitary } \\
\text { extract }+0.2 \mathrm{ml} \text { absorbed } \mathrm{FSH} \text { a/s }\end{array}$ & $16 \cdot 1 \pm 9 \cdot 1$ \\
\hline VII & 3 & $\begin{array}{l}\text { One adult male hamster pituitary } \\
\text { extract }+0.5 \mathrm{ml} \text { absorbed } \mathrm{FSH} \text { a/s }\end{array}$ & $7 \cdot 5 \pm 0.5$ \\
\hline
\end{tabular}

Pituitary extract and antiserum were injected subcutaneously at different sites. Autopsies were performed $24 \mathrm{hr}$ after the last injection.

* Control animals received normal rabbit serum (NRS). $a / s=$ antiserum.

antibodies to serum, tissue proteins and $\mathrm{LH}$ to neutralize FSH activity of rat and hamster pituitary extract was demonstrated and the results are presented in Table 3. It can be seen that the quantity of FSH antiserum used was sufficient to neutralize the FSH activity present in the pituitary extract of either rat or hamster.

\section{Ovulation experiments}

The ovulation experiments were carried out using three experimental

Table 4. The effect of administration of FSH or LH antiserum on the induction of ovulation in immature rats using either rat pituitary extract or ovine gonadotrophins as ovulatory stimuli

\begin{tabular}{|c|c|c|c|c|}
\hline Group & Treatment & $\mathcal{N}_{0} / \mathcal{N}$ & $\begin{array}{l}\text { Average no. } \\
\text { of ova } \pm S . D .\end{array}$ & $\mathbf{P}$ \\
\hline $\mathbf{I}$ & 20 i.u PMSG & $4 / 4$ & 0 & \\
\hline II & One rat pituitary extract & $4 / 4$ & $20 \pm 6 \cdot 3$ & \\
\hline III & $\begin{array}{l}\text { One rat pituitary extract }+1.0 \mathrm{ml} \\
\text { unabsorbed } \mathrm{FSH} \mathrm{a} / \mathrm{s}\end{array}$ & $1 / 7$ & 2 & \\
\hline IV & $\begin{array}{l}\text { One rat pituitary extract }+1.0 \mathrm{ml} \\
\text { absorbed FSH a/s }\end{array}$ & $4 / 4$ & $19 \pm 2 \cdot 5$ & II $:$ IV $>0.5$ \\
\hline $\mathrm{V}$ & $1.0 \mathrm{ml}$ absorbed FSH a/s & $0 / 3$ & 0 & \\
\hline VI & $\begin{array}{l}\text { One rat pituitary extract }+0.2 \mathrm{ml} \\
\mathrm{LH} \mathrm{a} / \mathrm{s}\end{array}$ & $0 / 6$ & 0 & \\
\hline VII & $200 \mu \mathrm{g} \mathrm{NIH} \mathrm{FSH}+0.2 \mathrm{ml} \mathrm{LH} \mathrm{a} / \mathrm{s}$ & $0 / 4$ & 0 & \\
\hline VIII & $20 \mu \mathrm{g} \mathrm{LH}+0.5 \mathrm{ml}$ absorbed FSH a/s & $4 / 4$ & $22 \pm 4 \cdot 8$ & $\begin{array}{l}\text { II: VIII }>0.1 \\
\text { IV:VIII } 0.1 \text { to } 0.5\end{array}$ \\
\hline
\end{tabular}

Each rat received 20 i.u. PMSG, followed by ovulating hormone 56 hr later. Autopsy was performed $18 \mathrm{hr}$ after the injection of ovulatory hormone.

$\mathbf{N}_{0}=$ Number of animals induced to ovulate. $\mathrm{N}=$ Number of animals in the group. a/s $=$ antiserum. 
Table 5. The effect of FSH and $\mathrm{LH}$ antiserum on the induction of ovulation in immature hamsters using hamster pituitary extract or ovine gonadotrophins as ovulatory stimuli

\begin{tabular}{|c|c|c|c|c|}
\hline Group & Treatment & $\mathcal{N}_{0} / \mathcal{N}$ & $\begin{array}{l}\text { Average no. } \\
\text { of ova } \pm \text { S.D. }\end{array}$ & $\mathbf{P}$ \\
\hline I & 20 i.u. PMSG & $4 / 4$ & 0 & \\
\hline II & 2 hamster pituitary extract equivalent & $4 / 4$ & $22 \pm 5 \cdot 2$ & \\
\hline III & $\begin{array}{l}2 \text { hamster pituitary extract equivalent } \\
+1 \mathrm{ml} \text { unabsorbed } \mathrm{FSH} \mathrm{a} / \mathrm{s}\end{array}$ & $3 / 3$ & $13 \pm 2 \cdot 7$ & $\begin{array}{l}\text { II }: \text { III } 0.05 \text { to } 0.1 \\
\text { III }: \text { IV } 0.05 \text { to } 0.1\end{array}$ \\
\hline IV & $\begin{array}{l}2 \text { hamster pituitary extract equivalent } \\
+1.0 \mathrm{ml} \text { absorbed } \mathrm{FSH} \text { a/s }\end{array}$ & $3 / 3$ & $24 \pm 6 \cdot 8$ & II $:$ IV $>0.5$ \\
\hline $\mathrm{V}$ & $\begin{array}{l}2 \text { hamster pituitary extract equivalent } \\
+0.2 \mathrm{ml} \mathrm{LH} \mathrm{a/s}\end{array}$ & $0 / 3$ & 0 & \\
\hline VI & $200 \mu \mathrm{g} \mathrm{NIH} \mathrm{FSH}+0.2 \mathrm{ml} \mathrm{L.H} \mathrm{a} / \mathrm{s}$ & $0 / 4$ & 0 & \\
\hline VII & $25 \mu \mathrm{g} \mathrm{LH}+0.5 \mathrm{ml}$ absorbed FSH a/s & $4 / 4$ & $23 \pm 4 \cdot 8$ & II $:$ VII $>0.5$ \\
\hline
\end{tabular}

Each hamster received 20 i.u. PMSG followed by ovulating hormone $56 \mathrm{hr}$ later. Autopsy was performed $18 \mathrm{hr}$ after injection of ovulatory hormone.

$\mathbf{N}_{\mathbf{0}}=$ Number of animals induced to ovulate. $\mathrm{N}=$ Number of animals in the group. a/s $=$ antiserum.

models - the first and second using immature animals, the ovulatory stimulus being of homologous or heterologous origin. In the third model, adult cycling animals were used, the endogenous ovulatory stimulus being neutralized with either FSH or LH antiserum.

It is clear from the data presented in Tables 4 and 5 that the trophic stimulus, whether an homologous pituitary extract or a purified heterologous gonadotrophin, is able to elicit a good ovulatory response in the animals primed with PMSG. While simultaneous treatment with FSH antiserum did not appear to influence ovulation, treatment with $\mathrm{LH}$ antiserum in all cases showed complete blockade of ovulation (Table 4, Groups VI and VII and Table 5, Groups V and VI). Attention should be drawn here to the ability of unabsorbed FSH antiserum to block ovulation, an effect which was abolished by 'cleansing' (Tables 4 and 5, Groups III and IV). The fact that FSH antiserum alone is unable to

Table 6. The effect of administration of antiserum to FSH or LH on ovulation at pro-oestrus in adult rats and hamsters

\begin{tabular}{|c|c|c|c|c|}
\hline Group & Treatment & $\mathcal{N}_{0} / \mathcal{N}$ & $\begin{array}{l}\text { Average no. } \\
\text { of ova } \pm \text { S.D. }\end{array}$ & $\mathbf{P}$ \\
\hline $\begin{array}{l}\text { Cycling rats } \\
\text { I } \\
\text { II } \\
\text { III }\end{array}$ & $\begin{array}{l}\mathrm{NRS}^{*} \\
0.2 \mathrm{ml} \mathrm{LH} \mathrm{a} / \mathrm{s} \\
0.5 \mathrm{ml} \text { absorbed FSH a/s }\end{array}$ & $\begin{array}{l}5 / 5 \\
0 / 6 \\
6 / 6\end{array}$ & $\begin{array}{c}13 \cdot 2 \pm 2 \cdot 9 \\
11 \cdot 0 \pm 3 \cdot 0\end{array}$ & I $:$ III $>0.1$ \\
\hline $\begin{array}{l}\text { Cycling hams } \\
\text { IV } \\
\text { V } \\
\text { VI }\end{array}$ & $\begin{array}{l}\text { NRS* } \\
0 \cdot 2 \mathrm{ml} \mathrm{LH} \mathrm{a/s} \\
0.5 \mathrm{ml} \text { absorbed FSH a/s }\end{array}$ & $\begin{array}{l}5 / 5 \\
0 / 5 \\
5 / 5\end{array}$ & $\begin{array}{l}7 \cdot 4 \pm 2 \cdot 1 \\
8 \cdot 2 \pm 1 \cdot 7\end{array}$ & IV $: \mathrm{VI}>0.5$ \\
\hline
\end{tabular}

$\mathrm{N}_{0}=$ number of animals induced to ovulate. $\mathrm{N}=$ number of animals in the group. $\mathrm{a} / \mathrm{s}=$ antiserum.

* Control animals received $0.5 \mathrm{ml}$ of normal rabbit serum (NRS). 
induce ovulation shows that it is free of LH contamination (Table 4, Group V). The system using heterologous preparations is particularly interesting since here an attempt was made to use immunologically 'cleansed' gonadotrophin preparations as ovulatory stimuli. The results clearly suggest that FSH is unable to induce ovulation in the absence of LH (Table 4, Group VII and Table 5, Group VI).

Essentially similar results were obtained using FSH and $\mathrm{LH}$ antisera in cycling adult rats and hamsters, $\mathrm{LH}$ antiserum being able to block ovulation while FSH antiserum was ineffective in inhibiting the ovulatory process (Table 6).

\section{DISGUSSION}

The results of the present investigation have shown that $\mathrm{LH}$ is the physiological trigger for ovulation. The ability of FSH to induce ovulation has been checked in various model systems and it can be concluded that, in the absence of $\mathrm{LH}, \mathrm{FSH}$ alone cannot induce ovulation. In the immature model systems using heterologous gonadotrophins, administration of FSH with $\mathrm{LH}$ antiserum at a time appropriate for injection of the ovulatory stimulus does not bring about ovulation. This experiment raises the question of whether LH antiserum, by neutralizing residual PMSG activity, is affecting the ovulatory response of the follicle to concomitantly administered FSH. The results of Sasamoto \& Kennan (1972), however, show that neutralization of PMSG at the time of, or $3 \mathrm{hr}$ before, injection of ovulatory hormone does not significantly affect the subsequent response of the follicle to ovulation stimuli.

It is evident from the results presented that although characterized FSH antiserum is able to bind and neutralize FSH specifically, it is unable to influence LH activity. Recent experiments on compensatory hypertrophy of the rat ovary and follicular development in hamsters, in which characterized FSH antiserum has been used, have shown that this antibody is able effectively to neutralize endogenous FSH (A. Jagannadha Rao, C. S. Sheela, S. Prahalad and N. R. Moudgal, unpublished results).

The methods used earlier to absorb FSH antiserum free of LH antibody involved the addition of exogenous $\mathrm{LH}$ till all the $\mathrm{LH}$ antibodies were removed. In such a method, the possibility of adding excess LH to the antiserum always exists. As seen in some of our recent experiments, the antibody to $\mathrm{LH}$ in the FSH antiserum was not always of the precipitating type detectable by the Ouchterlony test. By contrast, the present method permits the removal of both the precipitating and soluble type of antibodies to LH in one step. Further, the FSH antiserum by this method does not get contaminated with excess free LH and its antibody titre to FSH remains unchanged after absorption.

The basic difference between the present study and earlier investigations has been the attempt to achieve an exclusive test of the ovulation-inducing ability of FSH, i.e. in the total absence of endogenous and exogenous LH. It is probable that, under the conditions used by earlier investigators, FSH in some way exerted a permissive or additive influence on the minimal amounts of $\mathrm{LH}$ available to effect ovulation. The fact that administration of natural or synthetic LH-RF results in the concomitant release of both LH and FSH from the 
pituitary (Guillemin, 1971) may invalidate the idea that the appearance of FSH with LH in surge form would mean a rôle for the former in the ovulation process. The appearance of FSH in surge form just before ovulation recalls the suggestion of Schwartz (1969) that it may initiate fresh folliculogenesis for a subsequent cycle.

\section{AGKNOWLEDGMENTS}

The authors are thankful to the Ford Foundation, New York, and the Ministry of Health and Family Planning, Government of India, and the Indian Council of Medical Research, New Delhi, for financial help. We are appreciative of the technical assistance of Mr P. Pasupathy. The NIH-FSH-S7 and S8, and NIHLH-S14 preparations were gifts of the Endocrine Study Section, National Institutes of Health, Bethesda, Maryland, U.S.A. The PMSG was a gift from the Ayerst Laboratories. The highly purified preparations of FSH and LH used in the iodination and radio-labelled hormone-binding studies were the gifts of Dr H. Papkoff, Hormone Research Laboratories, University of California Medical Center, San Francisco, U.S.A.

\section{REFERENCES}

DaAne, T. A. \& Parlow, A. F. (1971) Periovulatory patterns of rat serum follicle stimulating hormone and luteinizing hormone during the normal estrous cycle: effects of pentobarbital. Endocrinology, $88,653$.

Goldman, B. D. \& MAhesh, V. B. (1969) A possible role of acute FSH release in ovulation in the hamster as demonstrated by utilization of antibodies to LH and FSH. Endocrinology, 84, 236.

Guillemin, R. (1971) Physiology and chemistry of hypothalamic releasing factors for gonadotropins: a new approach to fertility control. Contraception, $5,1$.

Harrington, F. E., Bex, F. J., Elton, R. L. \& Roach, J. B. (1970) The ovulatory effects of follicle stimulating hormone treated with chymotrypsin in chlorpromazine blocked rats. Acta endocr., Copenh. 65, 222.

Jagannadha Rao, A., Madhwa RaJ, H. G. \& Moudgal, N. R. (1971) Effect of gonadotropic antisera on ovulation in intact hamsters. Abstract No. 67. Society for the Study of Reproduction, 4th Annual Meeting, Boston, U.S.A.

Jagannadha RaO, A. \& Moudgal, N. R. (1970) An immunochemical study of ovine pituitary follicle stimulating hormone. Archs Biochem. Biophys. 138, 189.

Lostroh, A. J. \& Johnson, R. E. (1966) Amounts of interstitial cell-stimulating hormone and folliclestimulating hormone required for follicular development, uterine growth and ovulation in the hypophysectomized rat. Endocrinology, 79, 991.

MaCuintock, J. A. \& Schwartz, N. B. (1968) Changes in pituitary and plasma follicle stimulating hormone concentrations during the rat estrous cycle. Endocrinology, 83, 433.

Madhwa RaJ, H. G. \& Moudgal, N. R. (1970) Hormonal control of gestation in the intact rat. Endocrinology, 86, 874.

Midgley, A. R. \& JAFFE, R. B. (1968) Gorrelation of serum concentrations of follicle stimulating and luteinizing hormone during the menstrual cycle. F. clin. Endocr. 28, 1699.

Moudgal, N. R., Jagannadha Rao, A., Madhwa Raj, H. G. \& Maneckjee, R. (1970) Effect of sheep LH and FSH antisera in reproductive processes of the rat and hamster. Abstract No. 85. Proc. 52nd Endocrine Society Meeting, St Louis, U.S.A.

Moudgat, N. R. \& LI, C. H. (1961) An immunochemical study of ovine interstitial cell stimulating hormone (ICSH). Archs Biochem. Biophys, 93, 95.

PARLow, A. F. (1961) Bioassay of pituitary luteinizing hormone by depletion of ovarian ascorbic acid. In Human Pituitary Gonadotropins, p. 300. Ed. A. Albert. C. C. Thomas, Springfield, Illinois.

SAKIz, E. \& Guillemin, R. (1963) On the method of OAAD as a test for luteinizing hormone (LH). Endocrinology, 72, 804.

Sasamoto, S. \& Kennan, A. L. (1972) Effect of anti-PMSG serum on follicular ovulability in hypophysectomized immature female rats pretreated with PMS. Endocrinology, 91, 350.

Schwartz, N. B. (1969) A model for the regulation of ovulation in the rat. Recent Prog. Horm. Res. 25,1 . 